\title{
A Vow Remembered: Lawrence M. Judd and His Pledge to Kalaupapa
}

FRED E. WOODS

LAWRENCE RACED DOWN Nu'uanu Avenue on his bike, eager to gawk at the newly arrived U.S. Navy transport ships at the Honolulu harbor. Other activities involving celebrations, parades or royal visits had reached this waterfront in times past, but this was a different scene. As he slowly coasted closer to the pier he saw a crowd of Hawaiians of varying ages, mostly barefooted, was huddled behind an odd white picket fence awkwardly erected on the platform above the gangplank, intended to keep a separation between loved ones. Some of the people clung to the fence as they wept and howled. A young girl, cheeks glistening from tears, looked up and met the eyes of Lawrence. He felt her pain and searched for an explanation.

Lawrence rode to a uniformed man to ask what was happening and who these unfortunate people were. The man explained that the bereaved souls were family and loved ones of victims of leprosy who were being transported now to the Kalaupapa settlement. A large car-

Dr. Fred E. Woods completed a PhD in Middle East Studies from the University of Utah with an emphasis in Hebrew Bible in I99I. He is currently a professor at Brigham Young University in the College of Religious Education. Professor Woods has been a visiting professor at several universities and has lectured extensively in the United States and internationally. He has held a BYU Richard L. Evans Professorship of Religious Understanding and has authored a dozen books and scores of articles. Professor Woods has also produced several documentaries, including the film, "The Soul of Kalaupapa: Voices of Exile," http://www.byutv.org/ watch/5f63953e-de11-457b-99b7-c07b73eb084b/iris-soul-of-kalaupapa-voices-in-exile. His book titled Kalaupapa: The Mormon Experience in an Exiled Community is forthcoming March 2017 . This work will be published by the BYU Religious Studies Center and Deseret Book, 2017 .

The Hawaiian Journal of History, vol. $5^{\mathrm{O}}$ (2016) 
riage van arrived, and a health department officer led the patients out and onto the platform to say their last goodbyes to their families, who stood on the other side of the whitewashed fence. The wails and cries accelerated. All were careful not to draw near each other or touch. Brief tearful exchanges were made while health officials unloaded the patients' meager belongings from the van and placed them onto the cattle boat. Lawrence watched intently as the sorrowful procession of passengers walked slowly down the gangplank and found a place on the unpretentious, dirty inter-island cattle boat. Young and old waved their last farewells as they sailed toward their new lives of uncertainty and loneliness.

It was, at once, an unforgettable moment frozen in time, burned into the psyche of an impressionable young man. The scene of misfortune and heartache witnessed that day fashioned a rudder by which Lawrence would steer the rest of his life. Imaginations of becoming a celebrated naval captain dissolved, and a new vow took root in his heart. Somehow, some time, he would help these people of Kalaupapa. ${ }^{1}$

\section{Honorable Heritage}

The Judd family tree was rife with a legacy of respectable and dedicated public servants. Lawrence's grandfather, Dr. Gerrit P. Judd, and his grandmother, Laura Fish Judd, accepted an assignment from the American Board of Commissioners for Foreign Missions to serve as missionaries in Hawai'i. Leaving their New England home behind, in 1828 they fashioned a new one on the once dusty plains of Honolulu. Dr. Judd consecrated himself to public service and over the years held many impressive government positions. As a cabinet minister he advised and translated for King Kamehameha III, and as a diplomat he assisted in preserving the independence of the Sandwich Islands. Young Lawrence never knew his grandfather but said he felt his presence. Respect and admiration for the pioneering Judds was as much a heritage for him as were his genes.

Albert Francis Judd, Lawrence's father, served as Hawaiian Supreme Court Chief Justice for nearly two decades. He and his wife, Agnes Hall Boyd, parented nine children, Lawrence being their youngest child, born March 20, 1887 in Honolulu. ${ }^{2}$ 
Coupled with this philanthropic heritage was the Judd family tradition of daily Christian devotionals, consisting of father's Bible readings and mother's pipe organ hymnal. ${ }^{3}$ All this combined to forge a reliable moral character in Lawrence. In his late teens, one of his career objectives was to acquire enough finances to make good on his promise to help alleviate the hardships of leprosy patients. ${ }^{4}$ At last he discovered his goals could be realized through legal and influential public positions. He entered the arena and quickly rose in the ranks. Judd became a household name among Hawaiians and his service a well-known matter of public record. Not as duly noted is Judd's untiring devotion and service to patients stricken with leprosy (now officially recognized in the medical field as Hansen's disease). Judd worked as superintendent of Kalaupapa, the Hawaiian leprosy settlement on the island of Moloka'i (1947-1949), and later in Honolulu, as director of all Hansen's disease patients residing in Hawai 'i at either the settlement or in various hospitals (1949-1951).

\section{Family and Career Moves}

At the age of 22, Judd married Florence Bell Hackett, and they eventually became the parents of five children. ${ }^{5}$ During this period of his life, he gathered an abundance of experience working for the Whiting-Patterson Paper Company. First employed as a clerk, he quickly advanced as head of stock and shipping and later became a salesman. Throughout his tenure, he was known for his "hard work and integrity." Judd then went to work as a city buyer for Alexander \& Baldwin, a shipping and commission company, where he received additional skills in the market place. His employer felt that his "energy, perseverance and good judgment" would aid him in his future labors as the manager of a grocery department. ${ }^{7}$

After military service in World War I, he was invited by a group of very influential Honolulu businessmen to run as a Republican candidate for Hawai'i's Territorial Senate (1920). Initially apprehensive, Lawrence was eventually coaxed into entering the race by these men, who reminded him of the community service rendered by his father and grandfather. He relented when he thought of "what might be done by the Department of Health for the castaways of Molokai, still called lepers, and still symbolic of horror among the general public if 
only some dedicated person in politics could devote himself to their problems." He won the election. Decades later he admitted, "The plight of the patients has been on my mind nearly all my life." ${ }^{9}$

\section{Working With a Cause}

By 1921 , at the vigorous age of 34, Lawrence became a member of a public health committee that embraced the issues surrounding the suffering residents of Kalaupapa. He was influential in helping the Kalaupapa patients get electrical power: "I had a hand in it, in keeping with my childhood resolution. ... The recollection of that scene on the Honolulu-waterfront in my childhood days, when hopeless men, women, and children were herded to the Molokai settlement on an old cattle boat, still haunted me." 10

During the next two years (1921-1923) Judd made several visits to Kalaupapa and became friends with Brother Joseph Dutton, who compassionately served the patients for decades. ${ }^{11}$

Judd was elected president of the legislative senate in $1923 .{ }^{12}$ During his years of legislative work on the Territorial senate, Judd continued his visits to Kalaupapa and became "convinced that much more should and could be done to help the people there." ${ }^{13}$ Concerns at Kalaupapa continued to keep Judd's interest during the years he served as territorial governor of Hawai'i (1929-1934). During his tenure, he visited Washington, DC, to ask Congress for additional funding to help leprosy victims. ${ }^{14}$ Recalling his appointment to office in 1931, one of Judd's first thoughts was to require a "thorough study, followed by action to alleviate the condition of the leper settlement at Kalaupapa." He then "named a committee of prominent citizens, including physicians, to study the Kalaupapa situation, report, and make recommendations for action by the 1931 Legislature." ${ }^{5}$

In spite of the depression era, Judd managed to get a $\$ 65^{\circ}$,ooo appropriation to improve conditions at Kalaupapa, as well as the Kalihi Hospital in Honolulu, where leprosy patients were admitted. ${ }^{16}$ Improvements included a fifty-bed hospital, a mental-health ward, repaved streets, renovated cottages, small generators for homes, the construction of a store and gas station, and motion pictures available at a theater. ${ }^{17}$

In 1931 Judd addressed the Hawai'i Senate regarding his recent 
visit to the only leprosarium on the mainland, located in Carville, Louisiana. He was very impressed with the facility, noting that it housed 310 patients, contained farms, a laundry, an ice plant, a wellequipped kitchen, and nine- and eighteen-hole golf courses. He was most impressed that the families and relatives were free to visit the patients in their rooms with free social interaction and even allowed home visits for holidays. "I have hopes that we in Hawaii may raise the standards as high as those at Carvel [Carville]."18

Eventually, this hope was realized. One medical observer from Carville, who was apparently aware of both leprosy stations and the work with Hansen's disease, wrote to Judd after observing his work for a duration of only six months since the time he became superintendent:

We admire the work you are doing among the patients at your station in broadening their horizons and humanizing their hard lot. In some respects we are better off here than they, as we are only partly surrounded by water, but in other ways your patients are given more opportunities to rehabilitate themselves, which part of the program is so far sadly lacking at this hospital. ${ }^{19}$

His fun-loving nature came through when he told the committee how he had found nine Hawaiian patients at the institution and taken it upon himself to form a Hawaiian Club. They pulled out their guitars and ukuleles and had a "grand old time singing." Later, Governor Judd reflected, "I feel that if the Committee [on Public Health] has done nothing else that it has done a good job in bringing to the attention of the legislature, and to my attention, the need for doing something." 20

\section{A Golden Opportunity}

Several years after stepping down as territorial governor (1934), Judd was recruited as "Hawaii's unofficial ambassador of good will to the mainland United States," indicative of his aptitude to work well with others." ${ }^{21}$ With the bombing of Pearl Harbor, December 7, 1941, Lawrence volunteered for military service, but he did not pass his physical examination. ${ }^{22}$ He later received an appointment as the rent control administrator for Hawai' $i$, which he held for several years. ${ }^{23}$ 
But when the opportunity presented itself to further his contributions to the Kalaupapa community, he jumped on it, leaving the rent-control job behind without regret. ${ }^{24}$ The full-time job offer came by way of letter from H. A. Kluegel, superintendent of hospitals and the Kalaupapa settlement, to Harold W. Ross, who oversaw hiring for the Board of Health. Kluegel explained, "At Kalaupapa today there is need for the expansion of the scope of directed activities having to do with the welfare and well-being of the social aspect of the patients. The Board feels that Mr. Judd may well carry out this program in addition to the usual administrative duties of the position."25

Commencing in June 1947, Judd replaced William Waddoups, who then oversaw the Kalaupapa settlement. Judd recalled, "The Territorial Board of Hospitals and Settlements had appointed me superintendent of the settlement. Board members knew of my preoccupation with these victims. . . . When I was offered the job, I seized it." ${ }^{26}$ He was thrilled to learn that his wife, Eva Marie, knowing of his dream to better the lives of the patients, completely supported this appointment and subsequent move to the Kalaupapa community. ${ }^{27}$ Judd's enthusiasm to finally get his feet on the ground at the settlement and make a real difference was abundant.

In a letter to Kluegel, his superior, Judd described his arrival at the settlement as the newly appointed superintendent: "Mrs. Judd and I reached Kalaupapa on Thursday, June 12, 1947. We were met at the airport by most of the staff, many patients, and were accorded a most cordial reception." 28 Shortly thereafter, Judd convened a meeting in the social hall to get acquainted with the patients and staff. He struggled to contain his exuberance: "I fumbled for words to tell them, without sounding presumptuous, that I had come to live among them in the hope that I could better their lot." Immediately after this initial public meeting, Judd took Eva back to their private housing quarters and revealed his ambitious intentions: "I'm going to shake this place up. . . . I'll probably get tossed eventually. But I'm going to make changes fast, before the badly informed tossers can catch up with me." 29

His strong personality and determination took the community by storm. Bill Malo said that he and his fellow patients didn't like Judd initially because of his assertive ways in pressing to get things done, "but we liked him later. He pushed. We did not realize how far ahead of his time he was. . . He advanced the programs a lot." ${ }^{30}$ 


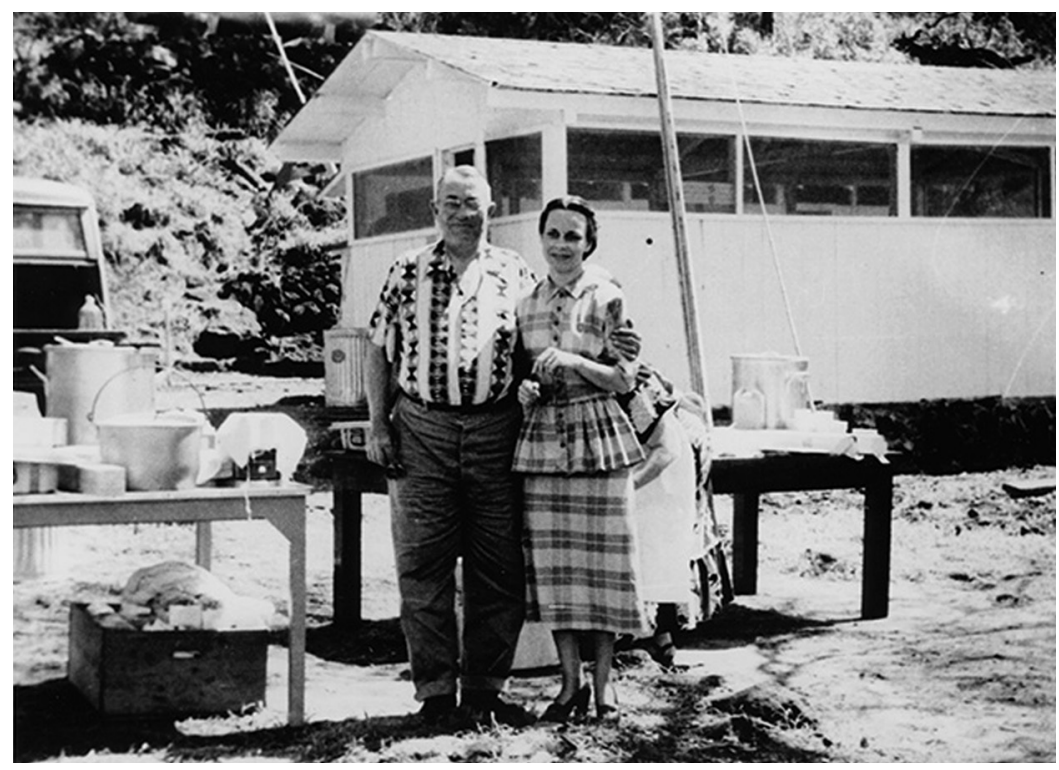

Lawrence Judd and his wife Eva at Kalaupapa, circa 1949. Courtesy of the National Park Service, Kalaupapa National Historic Park, Kalaupapa Historical Society Collection.

Judd's first goal was to clean the place up to instill greater selfrespect among the patients. His robust plan included discarding abandoned cars, as well as "mattresses, iron scraps, crates, packing material, bedsprings, rusty piles, defunct plumbing fixtures, oil stoves, termite-eaten lumber, and other junk that symbolized years of living in a state of hopelessness." When the dust settled, the community had hauled away six hundred truckloads of rubbish without the aid of a city sanitation crew. ${ }^{31}$ Long-time patient Danny Hashimoto remembered Judd's competent leadership in cleaning things up and especially appreciated how the cemetery was beautified. ${ }^{32}$

Newspapers recognized the good work the Judds were doing during their early tenure. One article, titled "Kalaupapa New Haven of Hope Under Superintendent L. Judd," mentioned a variety of things the Judds had accomplished in their first eighteen months of working at the settlement. Among the reported items were "a great Labor Day celebration, ... one weekend the most successful dance in the history of the settlement." The journalist also noted that therapy and 
adult education was moving ahead under the Judds' administrative era. Concerning this point, he wrote, "Mrs. Judd has approached this problem with the light of a crusader in her eyes. . . Classes in typing, domestic science and other trades are being given." Further, Mrs. Eva Judd had discovered two hand-looms that had not been used for years. She quickly mastered this craft and put those looms into operation. In addition, she made good use of feed sacks dyed for the looms and was moving ahead with rug weaving and block printing, with plans for pottery. She also directed the Dickens Christmas Carol one holiday season with funding plans for "makeup, costumes, and play script books." 33

The news editor also emphasized, "Many old taboos have been removed by Judd, giving a sense of normal living to the people of Kalaupapa. Every sensible precaution is taken, but many of the senseless rules that have been on the books for years have been removed." 34

Judd did away with whatever restrictions he deemed useless, like lifting the ban against patients and staff members dancing with each other. Edwin "Pali" Lelepali remembered Judd removing a barrier of potted plants on the dance floor and felt it was wonderful that now both the kokuas (helpers) and patients could mix while dancing. ${ }^{35}$ Judd reasoned, "Some precautions were taken at Kalaupapa that seemed unnecessary. There was no need for a high fence that surrounded the visitors' quarters. The sight of the twenty-foot barricade was a daily reminder to the patients of their segregation. I took it down." "36 Judd explained that the patients were not animals to be kept behind a fence. Pali reminisced that at the time the barrier was eliminated, "We could touch our families then. ... He did a wonderful thing." ${ }^{\prime 37}$

Rearranging his office for better interaction with patients was also promptly attended to. He recalled, "I likewise removed the railing that had separated the superintendent's desk from a bench where patients sat when they came to my office." 38 One patient recalled Judd's office and the removal of the barrier:

I remember the first time I went to . . . Mr. Judd's office and it was a big room. It was almost like twelve by twelve or maybe bigger yet. And when I opened the door, the door went against the wall over to the left, and then there was a railing from the side of the door straight across 
the floor to the wall on the other side. And so as I came into the room, I see Mr. Judd's desk in the center of the room . . . and I remember talking to him. ... The next time I went there was no railing. And he had it removed and I remember sitting on a chair right in front of his desk talking to him. ${ }^{39}$

Other patients also remembered this catalytic event: Referring to Judd, Olivia Breitha said, "I think that man was a psychologist at heart, because the first thing that came down was that railing around the office dividing the patient and the boss. . . . It gave us the feeling of belonging to the human race again." Pali likewise gave credit to Lawrence: "That's the guy who started tearing down the fences, ... the guy who really started opening up and making us feel a bit better." Adeline Ogawa confirmed, "Judd opened the gate. He brought life. . . . He brought acceptance." ${ }^{40}$

\section{Recreational and Social Organizations}

Under Judd's direction, the implementation of various community organizations helped foster accountability and responsibility among residents of Kalaupapa. Judd explained, "A craft shop was opened, education was emphasized, and a choral society organized. The staff began in every way possible to make the patients realize that they were part of a community that needed their services." 41

A great asset to the community was the charter for a Kalaupapa Lions Club that Judd managed to organize through his connections. Bill Malo, a member of the community since 1940, commented on the tremendous impact of the Lions Club:

In my opinion, the social interaction all came about because of this man. The biggest thing Mr. Judd did was to convince his brother to introduce the Lion's Club International to the settlement. Every year the Lions Club had a charter celebration, and people from the outside world would come to Kalaupapa to visit. . . . You were able to interact with other people socially, and it was here that we made contacts with the outside world. I made friends with people from all over who came to Kalaupapa with the Lions Club. . . . Developing these friendships helped me to shed some of the feelings of fear I had concerning whether or not I would be accepted. ${ }^{42}$ 
Only a week and a half after he arrived as superintendent, Judd reported that a Boy Scout camp had been organized in Kalawao under the "able direction of Mr. Harold Stein." Judd reported to Kluegel, "I have visited the camp three times so far and am pleased to find that the boys are having a splendid time." ${ }^{43}$ Decades later, patient Bill Malo, serving as an early assistant scoutmaster, remembered, "Judd was the one who had the first scoutmaster come in, Harold Stein." Malo, released from the settlement in 1957, added that it was also Judd who "started providing jobs for a temporary parole patient." 44

\section{Holidays and New Events}

From the time they arrived at the settlement, Judd and his wife were continually involved in social activities. In his first monthly report as superintendent, Lawrence reported, "Mrs. Judd and I have had but two free evenings this month, the others being taken up with receiving callers, returning same, attending meetings, and several dinners, including an informal picnic supper we gave at the superintendent's residence for all members of the staff." 45

Delegation among the patients was used to oversee recreational activities and to file regular reports regarding them, which Judd then added to his combined reports. For example, Timothy Waiamau issued the following memo that details one week of the "Recreational Activities for the month of February 1948":

February 2-Evening movie Feature Tarzan and the Huntress

February 3- Band Practice Isaac Condon Director

February 5-Band Practice Isaac Condon Director

February 6-Evening movie Feature The Yearling

February 9-Evening movie Feature The Big Fix

In the reports, the following week mentions yet more movies, additional band practice, and some special afternoon entertainment arranged by the Kiwanis Club of Honolulu. ${ }^{46}$ Activities like these continued in abundance throughout the Judd administration.

In a touching speech he made during the first Christmas season spent at the settlement, Judd revealed his tender feelings concerning the residents and Kalaupapa: "I know of no land nor people who can 
grow into one's heart more than Kalaupapa and its people. I am sure God smiled with great delight when HE finished Kalaupapa. He left with it and its people much of HIS love and the beauty of HIS own soul. I feel certain HE built himself into it and has since glorified it with His frequent presence." 47

The next Christmas, Judd arranged a Christmas radio performance by the Kalaupapa choir under the able direction of Mrs. Edith Warren Looms, a gifted vocalist and instructor who was recruited by Judd and gladly volunteered her services. After just six weeks of practice, the choral society was ready to record a broadcast for the 1948 Christmas holidays. The recording was played on several Hawaiian radio stations on both Christmas Eve and Christmas morning. The broadcast was a great success, and many listeners were touched, including Lawrence and Eva. Judd observed, "After so many years, they had won a little recognition by the outside world, and were no longer considered as outcasts." ${ }^{48}$ The choir continue long after the Judds had retired. ${ }^{49}$

Judd launched a Fourth of July celebration, which became a Kalaupapa field day, consisting of the following events: standing broad

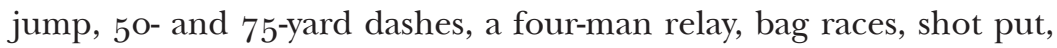
softball throwing and batting, potato races and even a "fat-man race." Winners received various prizes, which included pocket watches, a duck, a cigarette lighter, ash trays, a coffee maker, and vases. ${ }^{50}$

Judd served as Honorary Chairman of a "Regatta Day Swim Meet," held at the Kalaupapa Wharf. The events consisted of $25^{-}, 5^{\mathrm{O}-}, 75^{-}$ and $100-y a r d$ races for both boys and girls in freestyle and backstroke, as well as an individual medley and freestyle relay. The agenda for the day noted, "All first place winners will receive a CAKE as a prize. There will be six ducks let loose in the water and those that can catch them may keep them." ${ }^{51}$ One can only envision that these creative activities brought great amusement and cheer to the settlement.

One change that caught the attention of the patients as well as Judd's boss was the inauguration of sightseeing trips for the patients. More than one hundred fortunate patients (four at a time) were grateful that Judd had initiated such flights when he was the Kalaupapa superintendent. Bill Malo explained, "There were four of us who were given the first ride on the airplane. Mr. Judd said one afternoon, Andrews Flight Company is coming and will give you a ride around for $10-15$ minutes for $\$ 10.00$. Travel then started around the area." ${ }^{2}$ 
These brief flights around Moloka'i then expanded to other islands, such as Maui and Hawai' $i$. The only stops made were to refuel the engines when needed. Judd thought it would also be nice if the patients could enjoy brief meetings with family at fueling stations on various islands, with the understanding that no physical contact be made. One patient, Makia Malo, remembered Judd's flight plan:

He had arranged for patients to charter flights out of Kalaupapa, to go home to their home island. They could charter the flight and go over, fly to Big Island and they can go up there but they cannot leave the plane so at least they can see their family. And so all you had to do was telephone your family, they come here on a certain date. So you charter the flight and you go to Big Island or Maui, Lanai, wherever. It was the patient's choice. And so this happened a lot. ${ }^{53}$

Unfortunately, after seven months of joyful excursions, Judd's boss in Honolulu, H. A. Kluegel, caught wind of the sightseeing flights and ordered a detailed report of what had been going on as well as a list of every patient involved and who gave authorization. Among other things, Judd explained:

The plane flights were authorized by me in the absence of any rules, regulations or expressed policy of the board to the contrary. I do not know of any action that has contributed more to the joy of the patients concerned. These trips were definite morale builders, and, in my judgment, should not only be continued but encouraged.

The primary purpose of the trips, as initiated, was to provide sightseeing trips via airplane. The initial trips were made without landing at outside airports. As the trips were extended, it became necessary to refuel the planes and, thus, patients were able to arrange brief visits with relatives and friends at refueling points. . . In each case the destination of the plane was Kalaupapa airport. ${ }^{54}$

Kluegel's response was simple and to the point: "Stop the flights." That was the end of flying high. ${ }^{55}$

With the flights cancelled, Judd found a way to bring the world to Kalaupapa: importing entertainers via air travel. For example, one news editor observed that "an orchestra was flown in from Honolulu accompanied by six dancers of Honolulu nightclub fame." ${ }^{56}$ Superintendent Judd made sure there was an abundance of outside pro- 
fessional entertainment, which included big names such as "Shirley Temple, Irving Berlin, Edgar Bergen, Dennis Day, Olsen and Johnson, Art Linkletter, Tarbell the magician, Paul Robeson, and many outstanding entertainers." As a testament to Lawrence Judd's finesse, all entertainers performed free of charge at Kalaupapa. ${ }^{57}$

\section{Moral Considerations}

As with his predecessor, William Waddoups, Superintendent Judd was very concerned with the moral environment of the settlement. Soon after his appointment, he raised the same issues that Waddoups and representative residents of Kalaupapa had noted in December 1946. Among other things, adults who provided home supervision were to "encourage minors to attend church on Sunday." There was worry over the amount of alcoholic consumption by some adult patients, as well as the concern to keep the young away from smoking and drinking. ${ }^{58}$

With these challenges in mind, Judd quickly formed alliances with the religious leaders in the settlement by unifying the goals for the common good. In his autobiography, Judd specifically mentioned the cooperation and mutual respect he had for these assigned Kalaupapa spiritual leaders. He recalled the support of the Roman Catholic priest Father Patrick Logan, and the shared respect they had for one another: "Father Logan and I were able to deal quite successfully with problems of his parishioners." Another was the Protestant minister Reverend Alice Kahokuoluna: "a very fine woman . . . assigned by the Hawaiian Board of Missions to work at Kalaupapa. . . . I found her dedicated and cooperative," Judd recalled. A third influential church leader in the settlement Judd mentioned was Jonah Mahelona, who worked simultaneously as the presiding ecclesiastical officer for The Church of Jesus Christ of Latter-day Saints and as Kalaupapa's sheriff. ${ }^{59}$ Monthly police reports by Sheriff Mahelona frequently mention that intoxication was a recurring problem. Penalties often included fines, additional payment of court costs, and occasionally jail time. ${ }^{60}$

In spite of the combined efforts of the superintendent and these religious leaders to control the alcohol abuse, especially among the youth, problems continued. One patient, Nancy Talino, humorously recalled that the boys somehow found a way to sneak a few beers past 
Superintendent Judd, although they were fond of both Lawrence and his wife: "He was a man that everybody loved. Eva, his wife also greeted every patient with love. A nurse would warn the young men to hide their beer when Mr. Judd came to visit the hospital. They hid it in the toilet tanks." 61

\section{Youth Clubs}

Documents reveal that just three months after Judd took over as Kalaupapa's superintendent, programs were put into place to improve the lives of the young people. A memo dated September 2, 1947, recorded by a bright teenager named Edward Marks, who signed the document "Secretary," notes the following:

The meeting was opened by Mr. Judd to organize a club for the young people of Kalaupapa. After . . . advice, he stressed his full cooperation in organizing our club due to his interest in the younger sect. He also gave us the assurance that comm. Utterback of the American Legion is very willing to extend his full cooperation with his power to contribute to the success of our club. Mr. Judd also commented on some of the American Legions contributions such as trophies, cups, and athletic equipment. . . Mr. Judd then commenced in our election of officers. ${ }^{62}$

That same day, a memo recorded the names of the elected officers for a Girls Social Club and noted the elected officers. ${ }^{63}$ Three days later, minutes from their meeting indicate that rules and stipulations were established by which club members were to abide. These included "no swearing," and "all girls must not refuse to dance with the boys, if addressed politely." 64

When the boys met to shape their organization about this same time, it was proposed that the name of the club be "Young Men's Social \& Educational Club." The purpose of the club, as well as a constitution, was put in place: "The object of the club shall be promoting of Recreation, Loyalty, and other clean activity, among the young people of Kalaupapa. The club shall be composed of boys, residents of Kalaupapa. . . A majority of the members shall constitute a quorum." In addition, these were the bylaws established to provide order and to encourage the young men "to behave in a gentlemanly manner," which also included a tax of ten cents on those who used profanity. ${ }^{65}$ 
In addition to individual youth organizations for boys and girls, a "Young People's Social and Educational Club" was also formed, which was made up of both young males and females combined. The members agreed that each should pay a one dollar initiation fee and that there should also be a social held the third Saturday of each month. ${ }^{66}$

Judd believed that learning an instrument (he had played the violin as a child $)^{67}$ and performing in a band would boost the young people's morale and confidence. He arranged to have new instruments purchased, and a band was formed. Makia Malo, who went on to become a well-known Hawaiian story-teller, recalled his first public performance on the alto horn. Makia, feeling very inadequate with his new instrument, stood miming his part while the song was being played, not daring to put lips to horn. Judd, sensing the hesitance, whispered in Malo's ear, "Blow, boy, blow!" Makia recalled, "It came out pretty loud but it sounded almost like a fart, and people started to laugh. That was my debut." 68 These deliberate youth organizations, under the wise and experienced tutelage of Superintendent Judd, helped develop leadership and responsibility for the young people of Kalaupapa.

\section{Accomplishments Summarized}

Scores of other documents make it clear that Judd was determined to do all he could to improve conditions for both young and old at the settlement. At the dawn of 1949, Lawrence summarized his multiple doings as superintendent since his arrival two years earlier:

Substantial progress has been made in improving the welfare of the patients of the settlement. The general appearance and cleanliness of the settlement have been improved. Vocational, educational, and occupational therapy programs have been initiated. Additional opportunities for social intercourse have been instituted. The general moral tone of the settlement has been ameliorated. Worthwhile forms of entertainment_cultural, edificatory, as well as amusing-have been brought in for the benefit of the people. We have tried to recognize the patients as individuals, with widely different aptitudes. It is manifestly proper that the best humanitarian conscience and intelligence should be directed toward improving the lot of the patients. ${ }^{69}$ 
The gratitude patients expressed for the Judds is evident in both public and private correspondence. One expression particularly revealing occurs in a poem written for and about them in December 1948 by a patient named Joaquin De Luz, titled, "GRAND FOLKS":

He'd been in politics and knew all the ropes,

On committees he served both here and abroad.

Came to work and with him his wife,

A sweet gentle soul and a mother to all.

He's an old gentlemen with a rough exterior,

But beneath it all beat [s] a warm kind heart.

We just didn't take to him at the start,

Though as time went by he won our hearts.

A doughty old warrior and afraid of nought,

He still fights on for those near his heart,

Old prejudice and fears that persist and prevail

To make life miserable for those he holds dear.

His lovely wife is no less staunch,

In making our day both full and bright.

Together they work and their deeds are known,

To all who bless them with grateful hearts.

Devoting their twilight to works of love,

Day by day with hardly a pause.

Giving their measure of comfort and cheer,

To brighten the lives of those who live here. ${ }^{70}$

\section{EXPANDing AssignMENT}

During the years 1949-1951, Judd continued to oversee the Kalaupapa settlement, but his assignment expanded, as he explained:

After two years of serving patients at Kalaupapa, I returned to Honolulu and became the director of all Hansen's disease work in Hawaii, which included the supervision of the receiving hospital at the Kalihi suburb of Honolulu. Suspected cases were housed and screened at the Kalihi 
station, preliminary to transfer to Kalaupapa; or, if the suspects were lucky, discharged.

At the close of $195^{\circ}$, Judd prepared an impressive administrative report from the time of his appointment as Acting Director of the Division of Hospitals and Settlements (July 1949) for Dr. Charles L. Wilbur, Jr., president of the Board of Health. This memo provides a summation of accomplishments under his able direction, including construction projects and public services. Judd further noted that daily airmail service had commenced by March 1, 1950, telephone lines both inside and outside had been completed, and the Kalaupapa roads had been repaved.

In this memo Judd also recorded his work regarding the transition of housing for Hansen's disease patients when the Board of Health made the decision to close Kalihi Hospital and transfer them to the abandoned U.S. Navy facility at Pearl Harbor, which Judd optimistically designated as Hale Mohalu, "house of comfort." Not only did he oversee preparations necessary for the patients' arrival, Judd wisely anticipated the foreclosure of Kalihi Hospital and the availability of the Pearl City vacated barracks. He also used his adept business experience and maneuvering skills to successfully finagle his way into getting the Navy to turn over $\$ 25^{\circ}$,ooo of supplies at no charge. Judd recalled, "It occurred to me, that if the property had to be given up, the Navy might be reluctant to take back the equipment used by Hansen's disease patients. I was right." In addition, he launched the Hale Mohalu News, a monthly periodical, and opened the Hale Mohalu School in October, $195^{\text {o. }}{ }^{71}$

\section{Sincere THANKS}

Notes of gratitude for the service and kindnesses of the Judds are plentiful. Several sent expressions of gratitude for the Judds' birthday wishes: "Dear Mr. and Mrs. Judd, I wish to thank you both for your kindness in remembering me on my birthday, and for the birthday card you sent. . . God love you—Sincerely yours, Paul Harada." ${ }^{2}$

Another, writing from the Kalihi Hospital, concluded her warm letter, "I want to thank yo [sic] \& your dear wife once more for every thing. So may God bless you both to carry on the good work which 
the two of yo $[$ sic] are doing at Kalaupapa."73 During a time when the Judds were temporarily away, Kalaupapa resident Annie Reyher wrote, "Mrs. Judd Kalaupapa are not the same since you and Mr. Judd left. . . . My big aloha to you and Mr. Judd."74

Gratitude for practical changes during the Judd administration were also expressed for such things as expediting mail service years after Lawrence stepped down as Kalaupapa's superintendent: One patient wrote, "I hope that you and Mrs. Judd are in fine health and spirits. . . My sincere thanks and appreciation for your efforts in getting the patients here at Kalaupapa, direct air mail service which starts today. Many of us here feel that you are responsible for this most welcome service." ${ }^{5}$ On this same topic, S. Harada wrote, "'Mahalo,' for this daily Air 'Star' Service! Your efforts . . . have been finally successful, and I am most thankful."76

With such an array of activity and commitment, it is no wonder that the Judds drew the attention of the patients. About the time that Judd officially stepped down from his position as director of the Hansen's disease settlement and hospital, he received this revealing letter from a patient named Frank Mark:

Dear Papa Judd: Please accept my many thanks to you and Mrs. Judd for the beautiful and thoughtful birthday card you so kindly send me. I would like to say this one word that you are the only person and one man that made me feel like a real human being in all my 22 years in Kalaupapa and I really appreciate what you have done for me and the rest of the Settlement. You have brought real improvements that have never been done for the last 80 years and I can say the credit goes to papa Judd. I regret you leaving the post as Director. ${ }^{77}$

Mark was not alone in his sentiments. Other residents expressed their thanks by letter at the time of the Judds' departure. One couple wrote, "Dear Mr. \& Mrs. Judd, I'm thanking you for all you two has done for me \& James. . . . Thank you so much for your precious time you have thought [sic] me in art craft. Also my thanks to you Mr. Judd for being an understanding person and helpful." 78 Ruth M. Tathill expressed gratitude to the Judds for her "red roses." Further, she explained, "no one is more disturbed than I at your leaving us."79

David Mahelona also sent a heartfelt note to Lawrence reflecting on the many contributions Judd had made just days before his retirement: 
Dear Mr. Judd: I want to take this opportunity to extend to you my gratitude an appreciation for all the parts you have done toward our welfare and rehabilitation. Through your efforts and hard work as middle spokesman for us have made our segregation and separation from our family nearer to us in our family and business problems and have acted more like a father with kindliness and love. The part you have done will stand out for ever in the minds and hearts of those who have been close to you. I felt we have lost something precious. . . I hope you will never forget us and continue your effort to teach the community and the whole public to understand more of our misfortune as sufferer of Hansen's disease, and to remove the stigma. ${ }^{80}$

Resident Henry Hon wrote to Mrs. Judd, "Some of us here at Kalaupapa feel that the loss of Mr. Judd as Director of Hansen's Disease is a tragic event. . . . We appreciate very much his understanding of our problems." ${ }^{11}$

Patients under Judd's direction at Hale Mohalu (the new Hansen's disease hospital at Pearl City) felt much the same way as did the patients at Kalaupapa. Some 82 to 84 patients at Hale Mohalu signed a petition the month before Judd stepped down, expressing their strong desire that he remain in his position. ${ }^{82}$

\section{The Baton Is Passed}

Notwithstanding his excellent work as both a superintendent and then as a director of the Hansen's disease patients at the settlement and hospitals for a combined total of over four years, coupled with three decades of attention given to the rights and care of the patients, the Board of Health had made the decision that the administrative care of the Hansen's disease patients in Hawai'i should go to someone with medical experience; Lawrence had no such formal training. Thus, Judd resigned from his post, and the Board selected Dr. Ira D. Hirschy to replace him. However, the Board of Health did officially acknowledge the fine work Judd had accomplished and provided him with a "Resolution" as he left his directorship. Among other things it stated, "Lawrence M. Judd, since he became Governor of Hawai'i in 1929 has evidenced an unusual interest and concern in respect to the problem of Hansen's disease; and . . . has worked untiringly for the rehabilitation of the Hansen's disease patients and for the improvement of their health and general well being." 
Major Honolulu newspapers also publicly acknowledged the exceptional work Judd had performed. In an editorial by the Honolulu Advertiser titled "Lawrence M. Judd Steps Out," the following was noted:

Departure of Lawrence M. Judd, from his post as director of the division of Hansen's Disease, Territorial Board of Health, is regretted by patients, who hold for him a warm Aloha, and by the many friends and well-wishers of the former governor and of the important enterprise which he has directed so capably. His resignation marks the inauguration of a new policy, which calls for the services of a physician in the post of director instead of an administrator. Practical considerations may have led to the decision, but the patients will miss the warm sympathy and the human approach to their problems demonstrated by Lawrence M. Judd. The recent petition signed by 82 of the 84 patients at Hale Mohalu asking that he remain was a tribute to be cherished. ${ }^{84}$

Likewise, the Honolulu Star Bulletin ran an article under the headline "Lawrence M. Judd-'Doctor of Humanities,'” which included the following:

Lawrence M. Judd, for more than four years as an administrator in the territory's Hansen's disease division is bowing out November 17 [1951] as its director. The position calls for a medical doctor and Mr. Judd is not an M.D. The record of the past establishes, however, that he is, in a very real sense of the work, a 'doctor of humanities.' Not so many years ago, a sign at the outskirts of Kalaupapa settlement on Molokai might well have read, 'Abandon hope, all ye who enter here.' Today, thanks to the gains of medical science and Mr. Judd's humanitarian administration the plight of the Hansen's disease victim is no longer helpless, and he is no longer an outcast of the society.

This changing picture is reflected in Hale Mohalu, the new Hansen's disease hospital at Pearl City. Patients are no longer exiled to Kalaupapa, to be 'out of sight, out of mind.' They retain ties with the community, through such organization as the Lions club at Hale Mohalu in which patients and members of the Pearl City community work together on a program of service. Patients no longer spend dreary hours contemplating their unfortunate lot. They are busy with many activities. Cured patients who have returned to the community and taken jobs give them a new hope. The opportunity to serve gives them a new sense of being useful. 
Mr. Judd would be the last to claim all the credit for this change. The wonderful sulfone drugs, which have made cure possible, have had a great deal to do with it. And to medical directors at the settlement-a devoted succession of them-goes much of the credit. Judd's wise and understanding administration has been a big factor in the change. He has labored tirelessly to change outmoded public concepts of Hansen's disease....

It was delegate Joseph R. Farrington who said at the Hale Mohalu Lions charter night last summer, that Lawrence Judd will be remembered not so much for his distinguished service as a territorial senator and governor of Hawai' $i$, but for his work with the Hansen's disease patients. Lawrence has earned the community's gratitude and recognition as a true "doctor of humanities." 85

His work was also recognized by those who worked under his able direction. For example, on the day of his official retirement as Hawai'i's "Director of the Division of Hansen's Disease of the Department of Health," his colleague Hercules S. Mendonca expressed these tender feelings:

Today ... you are leaving. ... In so doing, you carry with you the deepest sorrow and keenest admiration of those who have been served as well as those who have been privileged to toil under you. . . The thought that you're no longer with me will be long in passing for the ideals you have established and the knowledge I've gained in your employ are treasured experience. I have gained something I never want to loose [sic]. Though I repeat I shall miss you, my loss cannot be compared to that of the sufferer of Hansen's Disease. You were an excellent boss and I have enjoyed my work with you. Aloha to two of the finest. Affectionately yours, Hercules S. Mendonca. ${ }^{86}$

Dr. Rufus K. Bopp, another colleague who had labored in the settlement, sent his sentiments: "I enjoyed working with you." 87 This same day, Dr. Bopp's wife, Ruth, sent an independent letter, stating, "We know how much all the Kalaupapa patients and those at Hale Mohalu are going to miss you. You have indeed been an angel of mercy to them." 88

The following month, Kalaupapa resident Alfred Chang expressed the sentiments of the patients in hoping that they would be remembered, and also letting Lawrence once again know that he certainly 
was not forgotten and was much appreciated for his charitable work at the settlement: "Thank you for all your kindness to us. Your acts of human charity are too numerous to mention and one letter could never do that justice. However, you may rest assured that many of us think of you often and know that you will continue to have an interest in the Hansen's Disease program. ${ }^{89}$

The Judds also remembered the patients, with whom they had become dear friends. As the winter holidays drew near, Timothy Waiaemaeu wrote from Kalaupapa, "It's nice to hear from you, we who are interested in your desire to bring some good towards those who are unfortunate as we are, can really appreciate all you have done."90

\section{New Assignments}

After he left official service to the Hansen's disease patients, Judd served five terms as president of the Hawai'i Foundation Association (Imua), which later became known as the Hawaiian Foundation for American Freedoms (1951-1953), and in March 1953 he was appointed as governor of American Sāmoa. ${ }^{91}$ On his way to Pago Pago to begin his term of office, he took a detour and visited the Fiji leprosarium on the island of Makogai. When Judd arrived, several hundred patients were seated on mats waiting for his address. Governor Judd spoke briefly, letting them know that he had been associated with the Hansen's disease work for several decades. He also tried to give the crowd hope by discussing the possibilities of full recovery from the use of the new sulphone drugs, which were now available. After he concluded his remarks, he then met with the patients who were from America Samoa, and they begged him to allow them to return to Pago Pago to be closer to their families. In a short time, Judd met their request. ${ }^{92}$

After serving in his office as governor for only a few months, Judd was forced to submit his resignation due to serious health concerns. Notwithstanding, he continued to think about Kalaupapa and the Hansen's disease patients, as well as those who served them. According to Judd's wife, Eva, in $195^{8}$ the Judds made a trip to Leuven, Belgium. Lawrence wanted to visit Damien's tomb; the selfless Belgian priest probably left a deep impression on Judd, as did this visit. ${ }^{93}$ Like Damien, Judd also had in mind the hearts of the patients and their conditions. In fact, the year before his death, Judd wrote the following 
letter, which again reveals that he continued to be interested in the details of Kalaupapa and had not forgotten the patients he served and worked with in the settlement:

Dear Timothy-Mrs. Judd and I have enjoyed your most interesting letter of January 11 th and thank you for it. Most of all, we both value your friendship and Aloha. We are pleased the new supt. is taking hold. Probably it is a good thing to have a settlement clean up. We are particularly interested in the plan of Dr. Hirschy to open up some of the settlement lands. We are pleased you continue to be in charge of social hall activities. . . We often recall our happy times when we lived at Kalaupapa plus many trials and tribulations. Mrs. Judd joins me in extending to you our best Aloha and all good wishes for 1967 Lawrence M. Judd. ${ }^{94}$

He continued to think about and battle to improve conditions for Hansen's disease patients through his entire life. It is also touching to learn that according to Eva, the last phone call that Lawrence ever made before passing was to one of the Kalaupapa patients. ${ }^{95}$ At the time of Judd's death on October 4, 1968, the Honolulu Star Bulletin noted, "At 81 he was still fighting. It was his public objection last March [1968] that called the State's attention to the need to reexamine its Hansen's Disease program. . . . It had hoped to include him on the committee to make the review. Death has now removed him from the scene." 96

The day following his death, Hawai'i's governor, John A. Burns, ordered the state flags flown at half-staff in honor of Lawrence M. Judd, the seventh governor of Hawai'i. He also remarked that Judd's distinguished family had made significant contributions to the development of the Islands. Further, Burns continued, "Throughout his life, Governor Judd remained loyal to the ideals of his family. His involvement in matters on the health and welfare of our people remained uppermost in his mind to the last, as exemplified by his recent expressed concern for the Hansen's disease patients at Kalaupapa. An important chapter of Hawaii's history ends with the passing of Governor Judd." 97

Services for Judd's funeral were held on October 7, 1968 at the Kawaiaha'o Church. On the funeral program was printed all of I Corinthians chapter 13, which focuses on the theme of charity. After the meeting concluded, a graveside Masonic ceremony was held at 
the Judd family plot in the O'ahu Cemetery. The family requested that in lieu of flowers, charities be made to the Lunalilo Home for elderly Hawaiians, which was Judd's last government assignment by the Hawaiian Supreme Court. ${ }^{98}$

At the time of Judd's departing, he was survived by his wife, Eva Marie Lillibridge, and a son, three daughters, nine grandchildren, and two great-grandchildren. ${ }^{99}$ Soon after his death, one of the patients who identified himself as "Stephen, A grateful leper," wrote this letter to Eva:

God love you very much. It is with deep sorrow that I write this letter to you, in the passing of a friend. . . You have lost a wonderful husband.... His passing from this life unto a joyous life with Christ is our prayer for this man who came into the world \& he knew only to... serve mankind \& I \& all lepers. ... Mr. Judd fought hard \& long for our behalves \& to the very last days before his passing he wanted nothing but the best for us. All I can say Mrs. Judd [is] as it is written in scripture, well done thou good \& faithful servant enter into the joys of my father. ${ }^{100}$

Eva, who lived three and a half decades after her husband's passing, made this revealing comment forty years after leaving Kalaupapa: "I think we felt it was the most rewarding two years of our lives."101 Further, like her husband Lawrence, Eva continued to stay in touch

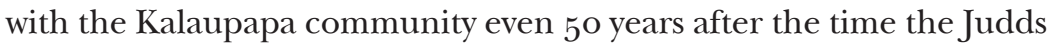
left the settlement. This is evidenced by a wonderful letter of thanks written to her by the wife of one of the patients in 2001 :

Dear Mrs. Judd-Wasn't that a lovely telephone visit we had Sunday? I enjoyed being with you! I am sending you an addressed envelope so your helpful assistant doesn't have to spend precious minutes on this. Just know that our greatfulness [sic] toward you is so profound for introducing the arts to Elroy [Makia Malo] \& a whole generation of children. They became different adults because of what you did. I thank you again \& again. My aloha-Ann Malo. ${ }^{102}$

As a tribute to the Judd legacy, the Kalawao Pavilion park area at the eastern end of the Kalaupapa peninsula was named the Lawrence McCully Judd Park at the request of the Kalaupapa Lions Club 
and the Patients' Advisory Council. ${ }^{103}$ Nearly a half century after his death, Lawrence and Eva Judd are remembered for their competent and charitable service. Lawrence is also recognized as the only man to have served as governor of two American territories. However, his service at Kalaupapa as superintendent (1947-1949) and his subsequent role as director of hospitals and settlements for Hansen's disease patients (1949-1951) seem to be the most telling chapter of a man and his wife who dearly loved the people of Kalaupapa. It also reveals the heart of a man who never forgot them from the time he was a boy until he drew his last breath. ${ }^{104}$

\section{Notes}

${ }^{1}$ Lawrence M. Judd, Lawrence M. Judd E Hawaii: [An Autobiography] (Rutland, VT and Tokyo, Japan: Charles E. Tuttle Company, 1971), 23-28.

${ }^{2}$ George R. Carter and Mary H. Hopkins, "A Record of the Descendants of Dr. Gerrit P. Judd of Hawaii, March 8, 1929 to April 16, 1922," A Genealogy of the Judd Family in Hawai i (Honolulu: Hawaiian Historical Society, Genealogical Series No. 3, 1922) 4, 16; http://en.wikipedia.org/wiki/Lawrence_M._Judd.

${ }^{3}$ Judd, Judd E Hawaii, 20.

${ }^{4}$ Judd, Judd E Hawaii, 69.

${ }_{5}^{5}$ Carter and Hopkins, A Genealogy of the Judd Family in Hawaii, 16, 18. After his children were grown, Judd divorced Florence Hackett in 1938 and soon married Eva Marie Lillibridge $\left(1915^{-2002}\right)$ who was twenty-eight years younger than Lawrence (1887-1968). Eva also outlived Lawrence by thirty-four years. See Judd, Judd E Hawaii, 233; http://www.findagrave.com/cgi-bin/fg.cgi?page $=$ gr\&GRid $=51782485$.

${ }^{6}$ Lawrence M. Judd Collection (LMJC), series M-420, box 1, fd. 4 "Correspondence, etc. 1909-1919," AH.

7 Employer (signature illegible), letter to Lawrence Judd, Nov. 23, 1914 , LMJC, series M-420, box 1, fd. 4 "Correspondence, etc. 1909-1919," AH.

8 Judd, Judd E Hawaii, 126.

9 Judd, Judd छे Hawaii, 259.

${ }_{10} \mathrm{Judd}$, Judd $\mathcal{E}$ Hawaii, 1 28, 130; Interview of Eva Marie Judd by Anwei Skinsnes Law, April 19, 1989, NPS, Kalaupapa National Historical Park Archive.

${ }^{11}$ Judd, Judd E Hawaii, 130-131. A decade later Judd also arranged to have Dutton, now blind and a bit senile, transported to Honolulu for medical treatment, where he passed away not long thereafter. Judd, Judd $\mathcal{E}$ Hawaii, 277.

12 Judd, Judd E Hawaii, 131.

13 Judd, Judd E Hawaii, 134.

${ }_{14}$ Judd, Judd E Hawaii, 175.

15 Judd, Judd Eं Hawaii, 141. 
${ }^{16}$ Judd, Judd Eं Hawaii, 147.

17 Judd, Judd Eं Hawaii, $25^{1 .}$.

18 "Hansen's Disease in Hawai'i Cited," Times-Picayune, [Louisiana] May 11, 1950, cited from "Leprosy. Clippings. Newspaper. 1950," LMJC, series M-420, box 16, fd. $25^{1}, \mathrm{AH}$.

${ }^{19}$ Gertrude S. Hornbostel, letter to Lawrence Judd, Dec. 10, 1948, LMJC, series M-420, box 19, fd. 282, "Correspondence, misc., etc.," AH.

20 "Transcript of Hearing on the Senate Bill No. 7o, before the Committee on Public Health of the Senate ... March 30, 1931," Territorial Legislature, LMJC, series, M-420, box 16, fd, 241, AH.

${ }^{21}$ Judd, Judd E Hawaii, 233.

22 Judd, Judd Eं Hawaii, 239.

23 Judd, Judd Eं Hawaii, 243-245.

${ }^{24}$ Judd, Judd $\xi$ Hawaii, 245.

${ }_{25}$ H. A. Kluegel, letter to Harold W. Ross, Apr. 16, 1947, LMJC, series, M-420, box ${ }_{15}$, fd. 207, "Kalaupapa. Employment. L. Judd," AH.

${ }^{26}$ Judd, Judd Eं Hawaii, 245.

27 Interview of Eva Marie Judd by Anwei Skinsnes Law, April 19, 1989, NPS, Kalaupapa National Historical Park Archive, Moloka'i.

${ }^{28}$ Lawrence M. Judd, letter to Mr. H. A. Kluegel, June 30, 1947, LMJC, series, M-420, box ${ }_{15}$, fd. 226, "Kalaupapa Res. Supt. report. June-September 1947 ," AH.

${ }^{29}$ Judd, Judd $\mathcal{E}$ Hawaii, 247.

${ }^{30}$ Interview of William Malo by Anwei Skinsnes Law, February 15, 1988, NPS, Kalaupapa National Historical Park Archive, Moloka'i, tape 4311.

31 Judd, Judd E Hawaii, 247-248.

32 Interview of Danny Hashimoto by Fred E. Woods, April 13, 2015.

${ }^{33}$ William J. Belknap, "Kalaupapa New Haven of Hope Under Superintendent L. Judd," Maui News, January 1, 1949, cited in "Leprosy. Clippings. Newspaper. 1949," LMJC, AH; Judd, Judd Eं Hawaii, 255.

${ }^{34}$ Belknap, Maui News, January 1, 1949.

${ }^{35}$ Interview of Edwin K. Lelepali by Fred E. Woods, April 13, 2015, typescript in author's possession. According to Elaine Remigio, Judd was the one who actually had the potted plants put in as a barrier. Before that time the staff could not participate on the dance floor at the same time. Remigio further explains, "Then gradually it worked where they didn't have the plants there, . . . and they danced with each other." Interview of Elaine Remigio by Anwei Skinsnes, Oral History Interviews conducted for the National Park Service $\left(19^{8} 5^{-1987}\right)$, vol. 2, tape \#32, of Elaine Remigio by Anwei Skinsnes, 8-9.

${ }^{36}$ Judd, Lawrence M. Judd E Hawaii, 264-265.

${ }^{37}$ Interview of Edwin "Pali" Lelepali by Fred E. Woods, April 13, 2015, typescript in author's possession. In a conversation following a lecture on Judd by the author at Kalaupapa, April 14, 2015 , another patient, John Arruda, age 91, also mentioned that he appreciated the opportunities that then became available 
with these changes so that patients and non-patients could interact. However, both Lelepali and Arruda noted that the younger patients did not like it when Judd later encouraged them to move to Hale Mohalu, which they feared meant that the Kalaupapa settlement would be shutting down. Yet Pali mentioned that the older patients, such as Alice Kamaka, continued to refer to Lawrence as Father Judd.

${ }^{38}$ Judd, Judd Eं Hawaii, 264-265.

${ }^{39}$ Interview of Makia Malo by Fred E. Woods and Ethan Vincent, August 2008, typescript in author's possession.

40 Anwei Skinsnes Law, Kalaupapa: A Collective Memory (Honolulu: University of Hawai'i Press, 2012 ), 466-467.

${ }^{41}$ Judd, Judd E Hawaii, 251-252.

42 Law, Kalaupapa, 467-468; Judd, Judd $\mathcal{E}^{2}$ Hawaii, $25^{2}$.

${ }^{43}$ Lawrence M. Judd, letter to Mr. H. A. Kluegel, June 30, 1947, LMJC, series, M-420, box ${ }_{15}$, fd. 226, "Kalaupapa Res. Supt. report. June-September 1947," AH. Concerning equipment for these scouting camp outs, Bill Malo explained, "We used to rent a donkey from David Kupele and bring our tents and fishing gear ... [for] hunting and fishing." Interview of William Malo by Anwei Skinsnes Law, February 15, 1988, NPS, Kalaupapa National Historical Park Archive, tape 4311 .

${ }^{44}$ Interview of Malo by Law, February 15,1988 , tape 4311 . Patients sent to Kalaupapa were given a number and were referred to as "inmates," though they had not committed any crime. In addition, words such as "parole" were also used by the Board of Health. Later, these negative terms were discontinued, but like a prison, Kalaupapa, selected largely for its natural barriers of sea and steep cliffs, kept patients from leaving the settlement.

${ }^{45}$ Judd, letter to Kluegel, June 3o, 1947, p. 1, LMJC, series, M-420, box 15 , fd. 226, "Kalaupapa Res. Supt. report. June-September 1947," AH.

${ }^{46}$ Timothy Waiamau, memo to Lawrence Judd, "Report of Recreational Activities for the month of February 1948," LMJC, series, M-420, box ${ }_{15}$, fd. 228, "Kalaupapa Res. Supt. report. January-March 1948," AH.

47 "To the People of Kalaupapa Settlement," LMJC, series, M-420, box ${ }_{15}$, fd, 227 , "Kalaupapa. Res. Supt. report. October-December 1947," AH.

${ }^{48}$ Judd, Judd E Hawaii, 253-254.

${ }^{49}$ Lawrence Judd, letter to Kalaupapa Choral Singers, Oct. 2, 1954, and Lawrence Judd, letter to James Davidson, May 15, 1955, "Choral Box Documents as found on top of Cab. 3 \& 4 AJA Hall," folder titled, "Incoming Property of Kalaupapa Choral Group," NPS, Kalaupapa National Historical Park Archive.

${ }^{50}$ Lawrence M. Judd, "Kalaupapa Field Day," and "Kalaupapa Field Day results and prizes," July 4, 1947, in records relating to Hansen's disease, Monthly Statistical \& Narrative Reports by the Superintendent of Kalaupapa, September 1944-July 1947, Series 26o, AH.

51 "Regatta Day Swimming Meet," LMJC, series, M-420, box ${ }_{15}^{5}$, fd. 226, "Kalaupapa Res. Supt. report. June-September 1947," AH. 
52 Interview of Malo by Law, February 15, 1988, tape 4311; http://hawaii.gov/ hawaiiaviation/chronology-of-aviation-in-hawaii/1940-1949; "Andrew Flying Service, LTD-Charter Rates," LMJC, series, M-420, box 14, fd. 14, "Kalaupapa. Air Service," AH.

${ }^{53}$ Interview of Malo by Woods and Vincent, August 2008.

${ }^{54}$ Judd, Judd $\mathcal{E}^{2}$ Hawaii, 260.

55 Judd, Judd E Hawaii, 262.

${ }_{56}$ Belknap, Maui News, January 1, 1949.

${ }^{57}$ Judd, Judd E Hawaii, 265; Stanley Stein, "Hansen's Disease in Hawai“i cited," Times-Picayune [Louisiana] May 1 1, 1950, cited in "Leprosy. Clippings. Newspaper. 1950," LMJC, AH.

${ }^{58}$ Lawrence M. Judd, letter to "the staff," July 7, 1947, in "Records relating to Hansen's Disease, Monthly Statistical \& Narrative Reports by the Superintendent of Kalaupapa, September 1944-July 1947, Series 260, AH. In his December 1946 superintendent's report to the Board of Health, Waddoups had voiced two main areas of concern to meet the needs of the Kalaupapa youth: "First, an appropriation to build a new suitable gymnasium and amusement and social center, second, the appointment of properly trained persons to organize and direct the spare time, amusements, athletics and social activities of our young people here. The moral status of our people here is deplorable, in too many instances. Our young people have little directed and planned amusements and social functions. In the absence of parents and home training, I feel it is imperative that some careful and thoughtful attention be given to the moral and character building of our young people. . . Along with such a programme, the sale and use of beer and wine can be more properly handled and controlled." William Waddoups, report to Board of Health, Dec. 1946 report, p. 3, "Records relating to Hansen's Disease, Monthly Statistical \& Narrative Reports by the Superintendent of Kalaupapa, September 1944-July 1947," Series 26o, AH.

${ }^{59}$ Judd, Judd E Hawaii, 263.

${ }^{60}$ Jonah Mahelona, report to Lawrence Judd, "Police Department Monthly Reports," LMJC, series M-420, box ${ }_{15}$, for the following dates: September 30 , 1947; fd. 226; November 20, 1947, fd. 227; August 31, 1948, fd. 230, AH.

${ }^{61}$ Interview with Nancy Talino by Fred E. Woods, January 18, 2015 , typescript in author's possession.

${ }^{62}$ Edward Marks, memo, Sep. 2, 1947, LMJC, series M-420, box ${ }_{15}$, fd. 226 , "Kalaupapa Res. Supt. report. June-September 1947," AH.

63 "Girls Club of Kalaupapa," LMJC, series, M-420, box 15, fd. 226, "Kalaupapa Res. Supt. report. June-September 1947," AH.

64 "[Girls Social Club] Minutes - Sept. 5, 1947 " LMJC, series M-420, box ${ }_{15}$, fd. 226, "Kalaupapa Res. Supt. report. June-September 1947," AH.

65 "Constitution and Bylaws of Young Men's Social and Educational Club; for the Young Men of Kalaupapa, Molokai," LMJC, series M-420, box 15 , fd. 226 , “Kalaupapa Res. Supt. report. June-September 1947," AH; Edward Macks, "Minutes of our meeting" Sep. 9, 1947. 
66 "Young People's Social and Educational Club," Sep. 24, 1947, LMJC, series M-420, box ${ }_{15}$, fd, 226 "Kalaupapa. Res. Supt. report. June-September 1947 ," $\mathrm{AH}$.

${ }^{67}$ Judd, Judd E्ञ Hawaii, 22.

${ }^{68}$ Interview of Malo by Woods and Vincent, August 2008; John Tayman, The Colony, (New York: Scribner, 20o6), 262.

${ }^{69}$ Lawrence M. Judd, titled "Kalaupapa Settlement," Jan. 15, 1949, "Kalaupapa. Misc. reports \& evaluation," LMJC, series M-420, box 15 , fd, 225 , AH.

70 "Grand Folks, dedicated to Mr. and Mrs. Lawrence M. Judd," LMJC, series, $\mathrm{M}-420$, box 19, fd, $280, \mathrm{AH}$.

${ }^{71}$ Lawrence M. Judd, letter to Dr. Charles L. Wilbur, Jr., Dec. 18, 195 o, pp.5-6, 8, LMJC, series M-420, box 15, fd. 225, "Kalaupapa. Misc. reports \& evaluation. 1947-1951," AH; Judd, Lawrence M. Judd Eं Hawaii, 278-280.

72 Paul Harada, letter to Lawrence and Eva Judd, July 10, 1950; Herbert Hayase, letter to Lawrence and Eva Judd, Nov. 3, 1951; S. Yamamoto, letter to Lawrence and Eva Judd, LMJC, series, M-420, box 19, fd. 279, "Correspondence. Kalaupapa and Hale Mohalu patients. Personal," AH.

73 Sanford J. Smith, letter to Mr. and Mrs. Judd, June 22, 1949, LMJC, series, M-420, box 19, fd. 279, "Correspondence. Kalaupapa and Hale Mohalu patients. Personal," AH.

74 Annie Reyher, letter to Mrs. Judd, Aug. 5, 1950, LMJC, series, M-420, box 19, fd. 279, "Correspondence. Kalaupapa and Hale Mohalu patients. Personal," AH.

${ }^{75}$ Henry Hon, letter to Mr. Judd, March 1, 1950, LMJC, series, M-420, box 19, fd. 279, "Correspondence. Kalaupapa and Hale Mohalu patients. Personal," AH.

76 S. Harada, letter to Mr. Judd, March 2, 1950, LMJC, series, M-420, box 19, fd. 279, "Correspondence. Kalaupapa and Hale Mohalu patients. Personal," AH.

77 Frank Mark, letter to Papa Judd, Oct. 16, 1951, LMJC, series, M-420, box 19, fd. 279, "Correspondence. Kalaupapa and Hale Mohalu patients. Personal," AH.

${ }^{78}$ Mr. and Mrs. James Jeong, letter to Mr. and Mrs. Judd, Nov. 14, 1951, LMJC, series, M-420, box 19, fd. 279, "Correspondence. Kalaupapa and Hale Mohalu patients. Personal," AH.

79 Ruth M. Tathill, letter to Lawrence and Eva Judd, Nov. 27, 1951, "LMJC, series, M-420, box 19, fd. 279, "Correspondence. Kalaupapa and Hale Mohalu patients. Personal," AH.

${ }^{80}$ David Mahelona, letter to Mr. Judd, November 12, 1951, LMJC, series M-420, box 19, fd. 279, AH.

${ }^{81}$ Henry Hon, letter to Mrs. Judd, Oct. 22, 1951, LMJC, series, M-420, box 19, fd. 279, "Correspondence. Kalaupapa and Hale Mohalu patients. Personal," AH.

${ }^{82}$ Patients of Hale Mohalu, "Petition," Oct. 10, 1951, LMJC, series M-420, box 19, fd. 281, "Correspondence. Retirement from Dept. of Health," AH. At the bottom of this document a note states, "All permanent (mentally normal) patients at Hale Mohalu have endorsed this petition with the exception of two (2), one of whom is being a minor desired to first obtain consent from his family." 
${ }^{83}$ C. R. Wilbar, et al. on behalf of Board of Health, "Resolution," Oct. 18, 1951, LMJC, series M-420, box 19, fd. 281, "Correspondence. Retirement from Dept. of Health," AH.

84 "Editorial in the Honolulu Advertiser," Oct. 20, 1951, "Lawrence M. Judd Steps Out," LMJC, series M-420, box 19, fd. 281, "Correspondence. Retirement from Dept. of Health," AH.

85 “Editorial," Honolulu Star Bulletin, Oct. 20, 1951, "Lawrence M. Judd-'Doctor of Humanities," LMJC, series M-420, box 19, fd. 281, "Correspondence. Retirement from Dept. of Health," AH.

${ }^{86}$ Hercules S. Mendonca, letter to Mr. Judd, Nov. 17, 1951, "LMJC, series M-420, box 19, fd. 281, "Correspondence. Retirement from Dept. of Health," AH.

${ }^{87}$ Dr. Rufus K. H. Bopp, letter to Mr. Judd, Nov. 18, 1951, LMJC, series M-420, box 19, fd. 281, "Correspondence. Retirement from Dept. of Health," AH.

${ }^{88}$ Mrs. Ruth K. H. Bopp, letter to Mr. Judd, Nov. 18, 1951, LMJC, series M-420, box 19, fd. 281, "Correspondence. Retirement from Dept. of Health," AH.

${ }^{89}$ Alfred Chang, letter to Mr. Judd, Kalaupapa, Dec. 1 1, 1951, LMJC, series M-420, box 19, fd. 279, "Correspondence. Kalaupapa and Hale Mohalu patients. Personal," AH; "Lawrence M. Judd," Kalaupapa Historical Society, vol. 2, no. 3, March 1983, Kalaupapa Historical Society Collection, file 1, cabinet 1, drawer 1, box 1, fd., "Kalaupapa Historical Society Newsletter- 1983," NPS, Kalaupapa National Historical Park Archive.

90 Timothy Waiaemaeu, letter to Lawrence Judd, Dec. 13, 1951, LMJC, series M-420, box 19, fd. 279, "Correspondence. Kalaupapa and Hale Mohalu patients. Personal," AH.

${ }^{91}$ Gene Hunter, "Ex-Governor Judd, 81, Dies," HA, Oct. 5, 1968, A-15; Judd, Judd $\mathcal{E}$ Hawaii, 281.

${ }_{92}$ Judd, Lawrence M. Judd E Hawaii, 282-283.

${ }^{93}$ Interview of Eva Marie Judd by Anwei Skinsnes Law, April 19, 1989, NPS, Kalaupapa National Historical Park Archive; Judd, Judd Eं Hawaii, 250).

${ }_{94}$ Timothy Waiamau Papers, Kala 20776, Box 1, fd. 7 "Incoming \& Outgoing Correspondence - Personal \& Lions Club 1954-1970, NPS, Kalaupapa National Historical Park Archive. (Thanks to Scott Williams for bringing these papers to my attention.)

${ }^{95}$ Interview of Eva Judd by Law, April 19, 1989.

96 "Lawrence M. Judd," HSB, Oct. 5, 1968, A-1o.

97 "Judd Funeral Tomorrow At Kawaiahao," Sunday Star-Bulletin E $\mathcal{E}$ Advertiser, Honolulu, Oct. 6, 1968 , A-1 o.

98 "Judd Funeral Tomorrow at Kawaiahao," Sunday Star- Bulletin, A-1 o; Judd, Judd $\mathcal{E}$ Hawaii, 296; "Service of Eternal Life for Governor Lawrence McCully Judd," LMJC, series M-420, box 23, fd. 334, "Miscellaneous. 1954-1968," AH.

${ }^{99}$ Hunter, $H A$, A-1.

100 "Stephen, a grateful Leper," letter to Lawrence Judd, LMJC, series, M-420, box 22, fd. 314, "General Correspondence. 1954-1968," AH; Timothy Waiamau, letter to Eva Judd, Oct. 8, 1968 , LMJC, series M-420, box 22, fd. 314 , "Gen- 
eral Correspondence. 1954-1968," AH; Timothy Waiamau, letter to Mr. A. A. Smyser, Oct. 8, 1968, LMJC, series, M-420, box 22, fd. 314, "General Correspondence. 1954-1968," AH.

${ }^{101}$ Interview of Eva Judd by Law, April 19, 1989.

102 Ann Malo, letter to Eva Judd, June 24, 2001, Kalaupapa item \# 12379, in fd. 1, NPS, Kalaupapa Historical National Park Archive.

${ }_{103}$ Dr. Ira D. Hirschy, letter to Mrs. L. M. Judd, Aug. 28, 1969, LMJC, series M-420, box 22, fd. 314, "General Correspondence. 1954-1968," AH.

${ }^{104}$ Hunter, $H A, \mathrm{~A}-15$. 
